\title{
Climatic and environmental records from the Far East Rongbuk ice core, Mt. Qomolangma (Mt. Everest)
}

\author{
1 Laboratory of Ice Core and Cold Regions Environment, Cold and Arid Regions Environmental and Engineering Research Institute, \\ CAS, Lanzhou 730000, China. \\ 2 Institute for Quaternary and Climate Studies, University of Maine, Orono, ME 04469, USA. \\ 3 Climate Change Research Center, Institute for the Study of Earth, Ocean and Space, University of New Hampshire, Durham, \\ NH 03824, USA.
}

During the Sino-American Expedition to Mt. Qomolangma (Mt. Everest) in May 1997, a $41 \mathrm{~m}$ ice core was recovered from an elevation of $6500 \mathrm{~m}$ from the northern branch firn basin of the Far East Rongbuk (FER) Glacier near Mt. Qomolangma (Mt. Everest). The ice core was dated down to AD 1814 by counting $\delta^{18} \mathrm{O}$ and major ion peaks calibrated to $\beta$ activity bomb layers. The average annual accumulation is $224 \mathrm{~mm}$ (ice equivalent).

Five cold periods and five warm periods have been reconstructed from the FER ice core records for the last 200 years and the general tendency of climatic change is warming, which agrees with recent temperature change in the Northern Hemisphere. The climatic records from the FER ice core agree with those from the Guliya ice core, suggesting that the climatic changes are consistent over the Qinghai-Tibetan Plateau, especially for the plateau-wide 20th-century warming trend.

Over the last 200 years, eight intense dust periods and nine lesser dust periods are recorded in the FER ice core. The more intense dust periods are during the 1830s to 1840s, and in 1880s and 1960s. The longest low dust period lasted from the 1890s to 1920s. Several maxima in crustal ion concentrations are consistent with strong dust storms recorded in the historical document from northwestern China. At the beginning of 20th century, $\mathrm{C}_{2} \mathrm{O}_{4}{ }^{2-}$ concentration from industrial source started to increase, notably during 1950s to 1980s.

\section{Introduction}

The Qinghai-Tibetan (Q-T) Plateau is one of the most imposing topographic features on the surface of the Earth. The sensible and latent heat flux released over the Q-T Plateau drives Asian monsoon circulation and strongly influences global circulation patterns (Murakami, 1987). Unfortunately, the longest continuous instrumental climate records for the region extend back only to AD 1935, and most records are only available from AD 1950. However, the Q-T Plateau possesses a diversity of natural archives from which detailed paleoclimatic and environmental records can be developed. The physical and chemical analysis of ice cores recovered from glaciers on the Q-T Plateau provide some of the best records of past climate change in the region (e.g. Mayewski et al., 1984; Thompson et al., 1989, 1995a, 1997, 2000; Yao et al., 1992, 1995; Qin et al., 2000). In order to better understand the climatic and environmental records preserved in snow and ice on the Q-T Plateau, several studies have been performed to investigate the spatial and temporal variation of $\delta^{18} \mathrm{O}$ and major ions in precipitation (Wushiki, 1977; Mayewski et al., 1983; Lyons et al., 1991; Wake et al., 1990, 1993; Yao et al., 1996a; Kang et al., 2000) and the relationship between aerosol and precipitation chemistry (Wake et al., 1994; Shrestha et al., 1997).

The vast extent of glaciers in the mountains of Q-T Plateau provide a convenient means to measure the depositional flux of atmospheric dust over a wide geographic area. The arid and semi-arid regions of central Asia are a major source area for windblown dust to the Northern Hemisphere (Gao et al., 1992). The peak in dust storm activity occurs throughout China from mid-February until late May, with a strong maximum in late April-early May (Merrill et al., 1989). Investigations of the chemistry of snow, ice, and aerosol samples collected from glacier basins indicate that the spatial variation of snow chemistry in the mountains of central Asia is controlled primarily by the influx of desert dust derived from the arid and semiarid regions of Asia (Wake et al., 1990, 1993, 1994; Shrestha et al., 1997; Kang et al., 2000).

The main crest of the Himalayas represents the climatic boundary between a region dominated by the influence of the Indian summer monsoon to the south, and the relatively cold, dry and continental climate which characterizes much of the Q-T Plateau to the north. The location of the Far East Rongbuk (FER) Glacier near Mt. Qomolangma (Mt. Everest) $\left(27^{\circ} 59^{\prime} \mathrm{N}, 86^{\circ} 55^{\prime} \mathrm{E}\right)$ on the boundary of the two climatic regions combined with the high elevation of the site, well above the influence of the boundary layer, provides a unique opportunity to describe and understand paleoclimatic and environmental change in remote regions (Figure 1). This paper focuses on the major ion and oxalate concentrations and $\delta^{18} \mathrm{O}$ values recorded in the FER ice core, to investigate the climatic and environmental change during recent 200 years in Mt. Qomolangma (Mt. Everest).

\section{Methodology}

In May 1997, a 41-meter core was collected from a site at $6500 \mathrm{~m}$ a.s.l. on the Far East Rongbuk Glacier, approximately $13 \mathrm{~km}$ north of the peak of Mt. Qomolangma (Mt. Everest) (Figure 1). FER is a valley glacier that stretches approximately $9 \mathrm{~km}$ and has an $\sim 150 \mathrm{~m}$ thick accumulation zone as measured at several locations with a portable radio echo sounding instrument. The ice core was recovered 


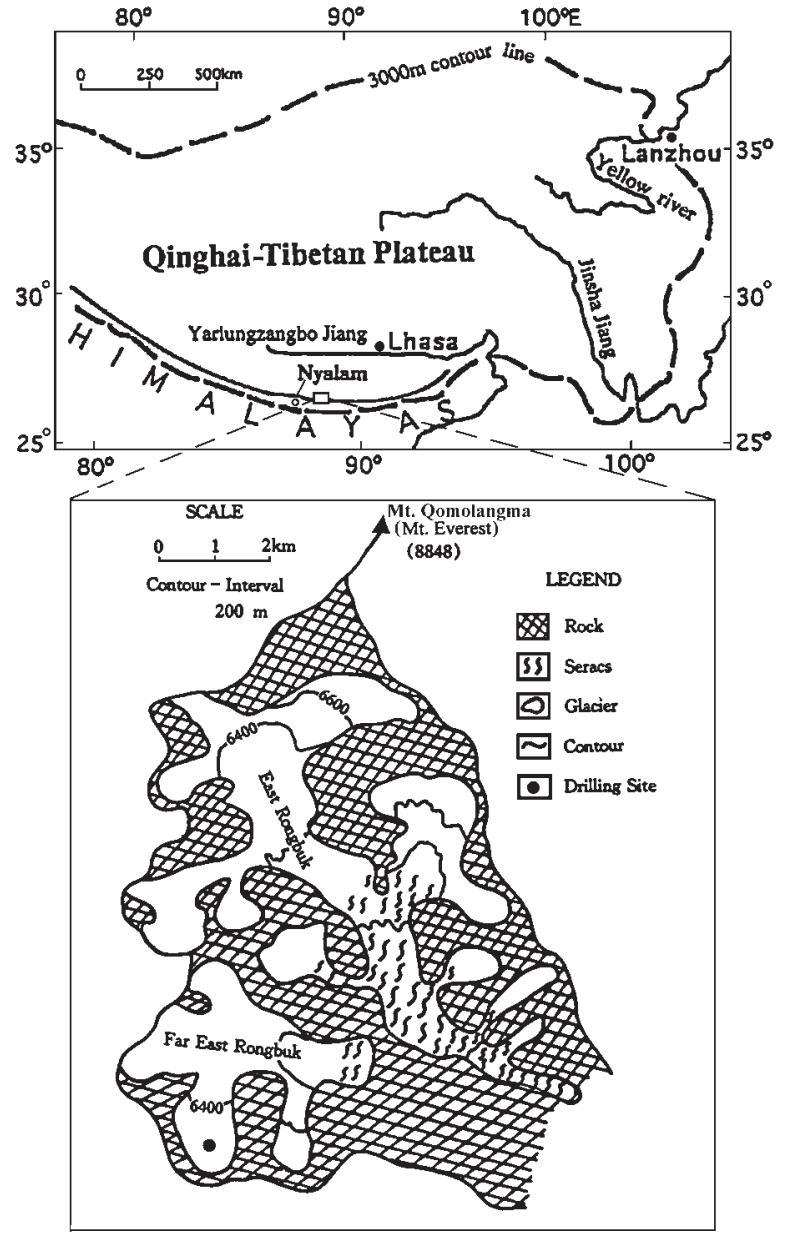

Figure 1 Sketch map of the Qinghai-Tibetan Plateau, the Far East Rongbuk glacier and the drilling site in 1997.

from a relatively flat portion of the accumulation zone, where glacier flow is assumed to be fairly laminar, using a new light weight drill (Eclipse). Reoccupation of previous survey sites reveals that FER glacier retreat has averaged $7.4 \mathrm{~m} / \mathrm{yr}$ since 1966 , similar to other larger valley glaciers on the north slope of Mt. Qomolangma (Mt. Everest) (Zheng et al., 1975; Ren et al., 1998).

The ice core was processed in the field in a dedicated clean trench excavated in the snowpack. All core handling and processing was performed by personnel wearing non-particulating clean suits, face masks, and polyethylene gloves. After the outer 10 20 mm of the core was scraped, the clean core was then cut into $0.04 \mathrm{~m} \mathrm{sec-}$ tions and placed in $60 \mathrm{ml}$ polyethylene cups. The ice core samples were melted just prior to analyses for major ion concentrations via ion chromatography on a Dionex $4000 \mathrm{i}$ at the University of New Hampshire using methods described elsewhere (Buck et al., 1992). Oxygen isotope samples $\left(\delta^{18} \mathrm{O}\right)$ were measured on a Finnigin MAT252 mass spectrometer at the Cold and Arid Regions Environmental and Engineering Research Institute, Chinese Academy of Sciences.

Current mean annual temperature (based on standard $10 \mathrm{~m}$ depth temperature) is $-7^{\circ} \mathrm{C}$ at the core site. As commonly observed throughout almost all elevations on the Q-T Plateau and Himalayas (Mayewski et al., 1981; Thompson et al., 1988), melting does occur during at least a portion of the year. Preservation of annual signals in the FER $\delta^{18} \mathrm{O}$ plus several chemical species (e.g., $\mathrm{Na}^{+}, \mathrm{Ca}^{2+}, \mathrm{SO}_{4}{ }^{2-}$, $\left.\mathrm{Mg}^{2+}\right)$ series can be assumed based on calibration with known bomb horizons ( $+/$ - one year counting error at this level) identified in the well-preserved total $\beta$-activity profile from this core (Qin et al., 2000). Melting is, therefore, assumed to be confined within annual layers, thus, preserving the annual signal used to date the record. We counted 184 annual layers back through the entire $41 \mathrm{~m}$ ice core, indicating that our record spans the time period from 1814 to 1997 (a resolution of 5.5 samples per year). Details of the dating methods are described by others (Hou et al., 1999; Qin et al., 2000). The average annual accumulation is $224 \mathrm{~mm}$ (ice equivalent). Variations of $\delta^{18} \mathrm{O}$ and major ion concentrations with time are shown in Figure 2.

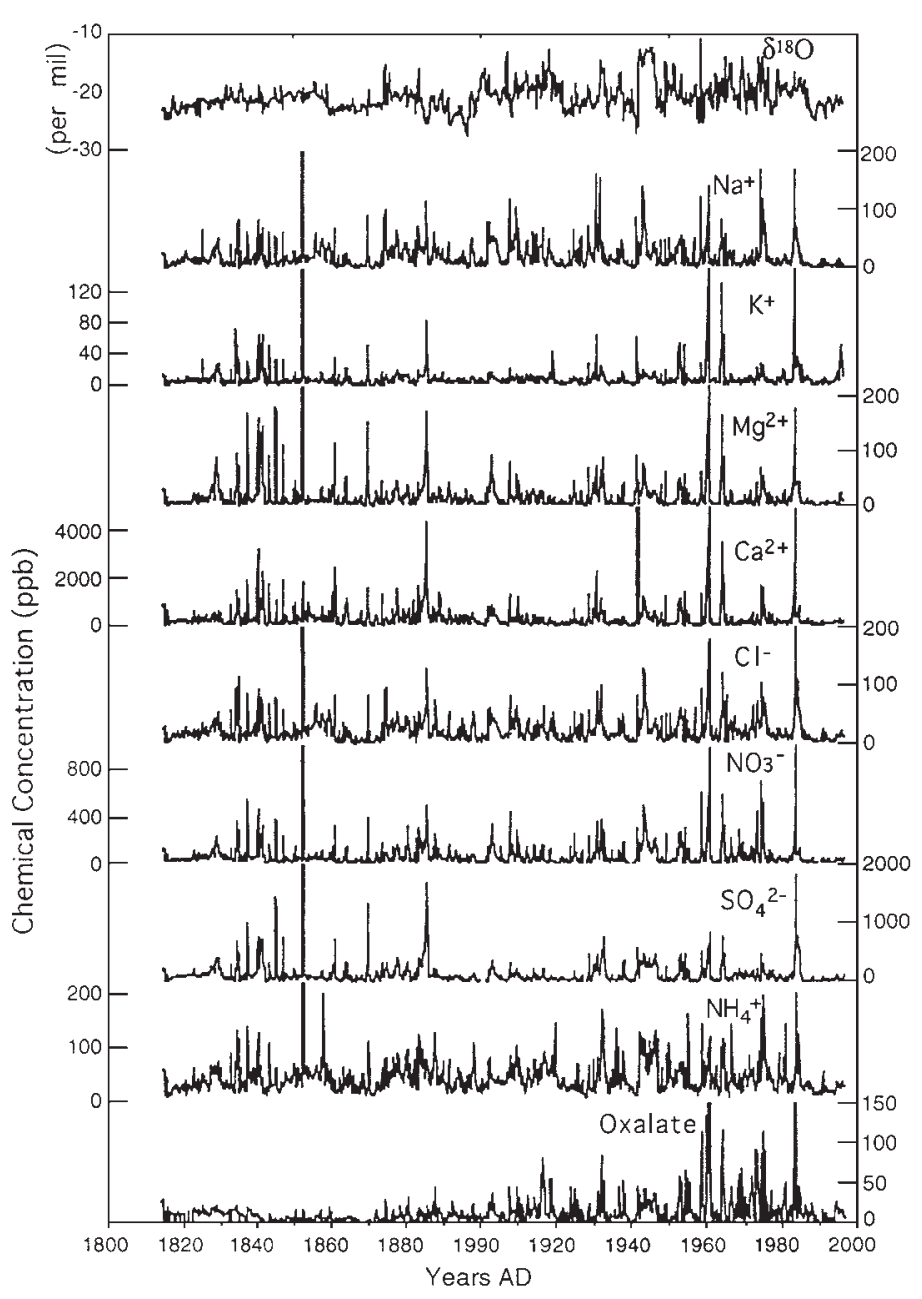

Figure 2 The concentration variations of chemical species with time in the Far East Rongbuk ice core.

\section{Results and discussion}

\section{Climatic records in FER ice core}

In central Himalayas, $\delta^{18} \mathrm{O}$ values increase from winter to spring reflecting change in temperature of condensation, and the lowest $\delta^{18} \mathrm{O}$ values occur in late summer indicating that $\delta^{18} \mathrm{O}$ is controlled by an "amount effect" during the monsoon season (Wushiki, 1977; Wake et al., 1995; Kang et al., 2000). Although the seasonal variations of $\delta^{18} \mathrm{O}$ are influenced by both temperature and precipitation, the long-term $\delta^{18} \mathrm{O}$ records (e.g. since the Last Glacial Age) in ice cores from tropical regions are still used as a proxy for temperature (Thompson et al., 1995b, 1997). Recent studies indicate that the change of long-term $\delta^{18} \mathrm{O}$ in the Dasuopu Ice Core from central Himalayas is consistent with temperature change over the Northern Hemisphere (NH) (Thompson et al., 2000). Apparently, not only the fluctuations, but increasing tendency of FER $\delta^{18} \mathrm{O}$ also agrees with those of NH temperature (Jones et al., 1986; Qin et al., 2000) (Figure 3 ), and with those of Guliya ice core $\left(35^{\circ} 17^{\prime} \mathrm{N}, 81^{\circ} 29^{\prime} \mathrm{E}\right)$ from the northwestern Q-T Plateau (Yao et al., 1996b) (Figure 4). It may be deduced that the FER $\delta^{18} \mathrm{O}$ changes are mainly dominated by "temperature effect". Based on this, the climatic change will be discussed. 
The fluctuations of FER $\delta^{18} \mathrm{O}$ indicate that there are 5 cold periods and 5 warm periods from the beginning of the 19th century to the 1980s (Table 1; Figure 3 and 4). Since the beginning of 19th century, climate change recorded by FER $\delta^{18} \mathrm{O}$ is generally consistent with temperature change in the NH. The exception is that the third warm period and the fourth cold period in the earlier 20th century are contrary to that of the $\mathrm{NH}$. This may be caused by the difference between regional and hemispheric climate change. The FER $\delta^{18} \mathrm{O}$ changes have a good agreement with that from Guliya ice core (Figure 4), suggesting that climate changes are consistent in regional scale over the Q-T Plateau from the beginning of 19th century. Especially, the 20th-century warming trend recorded in the FER ice core agrees with that of plateau-wide warming recovered from other ice core records over the Q-T plateau (Yao et al., 1995; Qin et al., 2000; Thompson et al., 2000). Compared to the monsoon precipitation from northwest India adjacent to Mt. Qomolangma (Mt. Everest) (Sontakke et al., 1996) (Figure 3), high $\delta^{18} \mathrm{O}$ values from FER ice core correspond to low precipitation in 1870s and the earlier 20th century, and low $\delta^{18} \mathrm{O}$ values to high precipitation during $1880 \mathrm{~s} \sim 1890 \mathrm{~s}$. This inverse association between FER $\delta^{18} \mathrm{O}$ and precipitation may be expected given the influence of precipitation amount on $\delta^{18} \mathrm{O}$ (Wushiki, 1977; Rozanski et al., 1992; Wake et al., 1995; Kang et al., 2000).

Table 1 Warm and cold periods recovered by $\delta^{18} O$ in the Far East Rongbuk ice core

\begin{tabular}{c|c|c|c|c}
\hline \multirow{2}{*}{ Events } & \multicolumn{2}{|c|}{ Cold period } & \multicolumn{2}{c}{ Warm period } \\
\cline { 2 - 5 } & Period (AD) & Duration (years) & Periods (AD) & Duration (years) \\
\hline 1 & $\sim 1826$ & & $1826 \sim 1858$ & 32 \\
2 & $1858 \sim 1874$ & 16 & $1874 \sim 1886$ & 12 \\
3 & $1886 \sim 1898$ & 12 & $1898 \sim 1921$ & 23 \\
4 & $1921 \sim 1943$ & 22 & $1943 \sim 1953$ & 10 \\
5 & $1953 \sim 1974$ & 21 & $1974 \sim 1986$ & 12 \\
\hline
\end{tabular}

Since 1930s, summer precipitation in India fluctuated slightly and its tendency is not evident, however, the $\delta^{18} \mathrm{O}$ fluctuation is larger (Figure 3). Over the last 40 years, there are also some reverse tendencies between FER $\delta^{18} \mathrm{O}$ and annual precipitation from Xigeza Meteorological Station (e.g. in 1960s, 1970s, and 1980s) (Figure 5), as well as some similar trends between FER $\delta^{18} \mathrm{O}$ and annual temperature (e.g. in the earlier 1970s and in the middle of 1980s). These may indicate that FER $\delta^{18} \mathrm{O}$ records are influenced by both precipitation and temperature, or even more than these two factors in the last decades. A recent study (Qin et al., 2000) points out that controls on the isotopic fractionation of moisture deposited on the southern margin of the Plateau have changed over the last few decades. The increase in temperature over the last few decades (Kang et al., 1998) may have led to changes in atmospheric circulation that have resulted in a decrease in moisture flux to the Plateau. Especially since 1980s, influence for FER $\delta^{18} \mathrm{O}$ may be not simply limited to precipitation and temperature but more complicated, and should be the combination of many factors and processes.

\section{Environmental records in FER ice core}

\section{Variations of atmospheric dust}

The high concentration of major ions recorded in the FER ice core occur simultaneously and their variation tendency is similar (Figures $2,6) . \mathrm{Ca}^{2+}, \mathrm{Mg}^{2+}$ and $\mathrm{SO}_{4}{ }^{2-}$ in snow and ice come from crustal dust in the central Himalayas (Wake et al., 1993; Kang, et al., 2000), thus, the variation of atmosphere dust in Mt. Qomolangma (Mt. Everest) since the beginning of 19 th century can be discussed via $\mathrm{Ca}^{2+}, \mathrm{Mg}^{2+}$ and $\mathrm{SO}_{4}{ }^{2-}$.

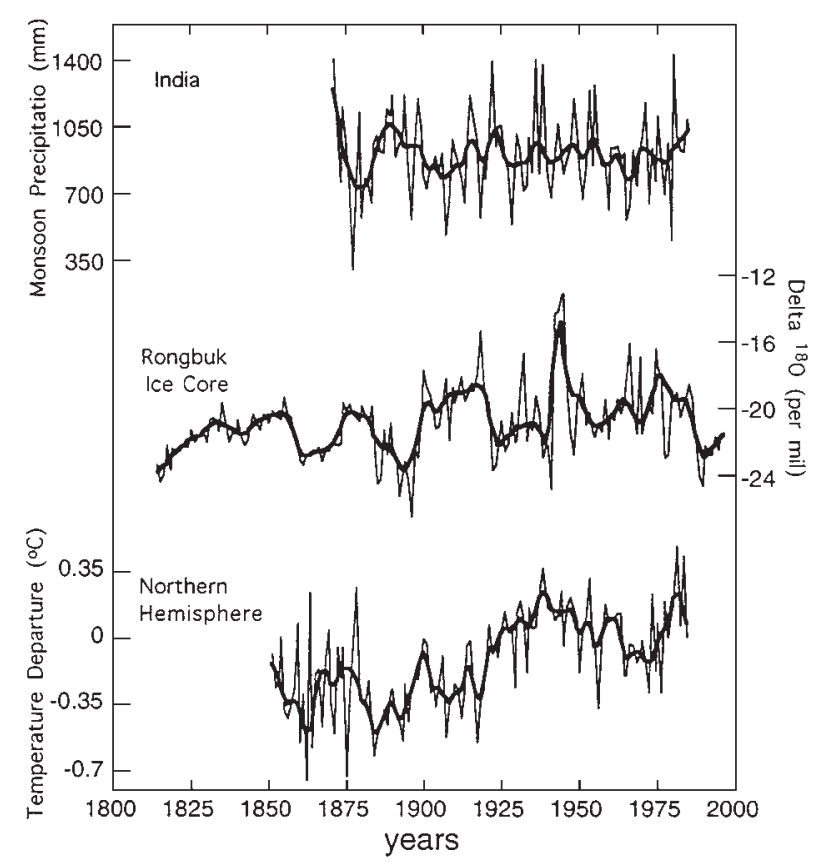

Figures 3 The variations of $\delta^{18} \mathrm{O}$ in the Far East Rongbuk ice core, compared with monsoon precipitation in the northeastern India and the temperature departure in the Northern Hemisphere (the fine line is annual value and the coarse line is 5 point smoothing value).

The variations of atmosphere dust since 19th century recorded in the FER ice core are summarized in Table 2. It shows that the periods of intense dust are during the 1830s to 1840s, and the 1880s and 1960s. However, a period of less dust, from the end of 19th century to late 1920 s, was the longest one, in which there was a secondary stage of intense dust around 1903. Since 1960s, the dust storm events, which happened in Northwestern China most strongly and extensively in 1961, 1983 and 1984 (Qian et al., 1997), are synchronously recorded in the FER ice core (dust maxima years in Table 2), suggesting that the dust storms occurred in mid-Asia may be transported to the Northern slope of the Mt. Qomolangma (Mt. Everest), though this process depends on dust transportation from north to south, while dust is generally transported from west to east or from northwest to southeast in mid-Asia (Xu et al., 1997). Dust in FER ice core may also be influenced by spring dust storms from southwestern Asia. Because of the extensive dust storms in southwestern Q-T Plateau (e.g. 10 20 days of dust storms per year) (Lian, 1997), dust

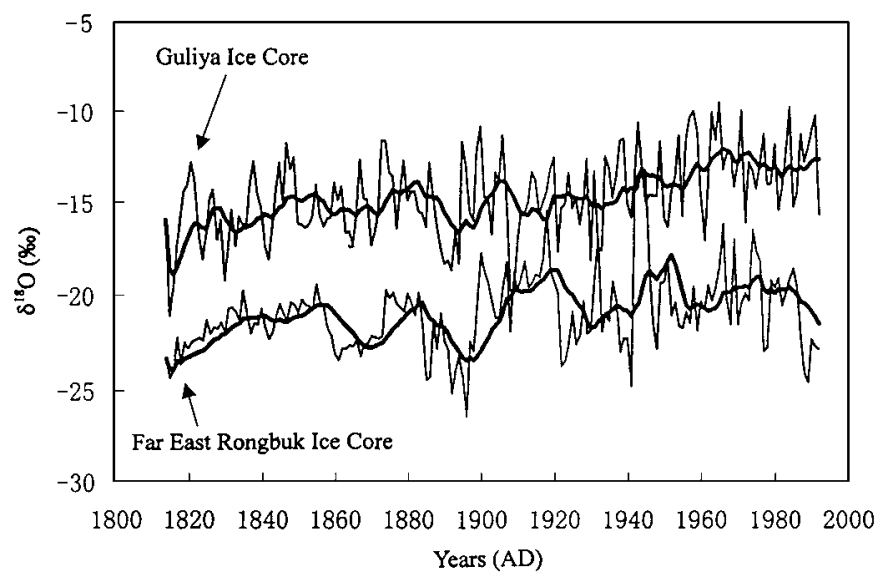

Figure 4 The comparison of $\delta^{18} \mathrm{O}$ in the Far East Rongbuk ice core and the Guliya ice core (the fine line is annual value and the coarse line is 11 point smoothing value). 
Table 2 Intense and lesser dust periods recovered by crustal ions in the far East Rongbuk ice core.

\begin{tabular}{ccccc}
\hline \multicolumn{3}{c}{ Period of intense dust } & \multicolumn{2}{c}{ Period of lesser dust } \\
\hline Period & Duration (years) & Years of Maximum & Periods & Duration (years) \\
& & & $\sim 1827$ & \\
$1827 \sim 1843$ & 16 & 1834,1837, & $1843 \sim 1852$ & 9 \\
$1852 \sim 1865$ & 13 & 1840,1841 & & \\
$1878 \sim 1893$ & 15 & 1860,1864 & $1865 \sim 1878$ & 13 \\
$1928 \sim 1934$ & 6 & 1885 & $1893 \sim 1928$ & 35 \\
$1943 \sim 1949$ & 6 & 1941,1943 & $1949 \sim 1960$ & 11 \\
$1960 \sim 1967$ & 7 & 1961,1964 & $1967 \sim 1974$ & 7 \\
$1974 \sim 1977$ & 3 & 1975 & $1977 \sim 1983$ & 6 \\
$1983 \sim 1968$ & 3 & 1983,1984 & $1986 \sim$ & 9 \\
\hline
\end{tabular}

storms from the Plateau are perhaps the one of the most likely sources for ice core crustal species. Additionally, local rock around the FER Glacier may also be dust source. In summary, the change of dust species reflects combination of sources from mid-Asia, southwestern Asia, and southwestern Q-T Plateau, as well as local rock. Among these sources, the dust storms from the vast mid-Asia may be dominant.

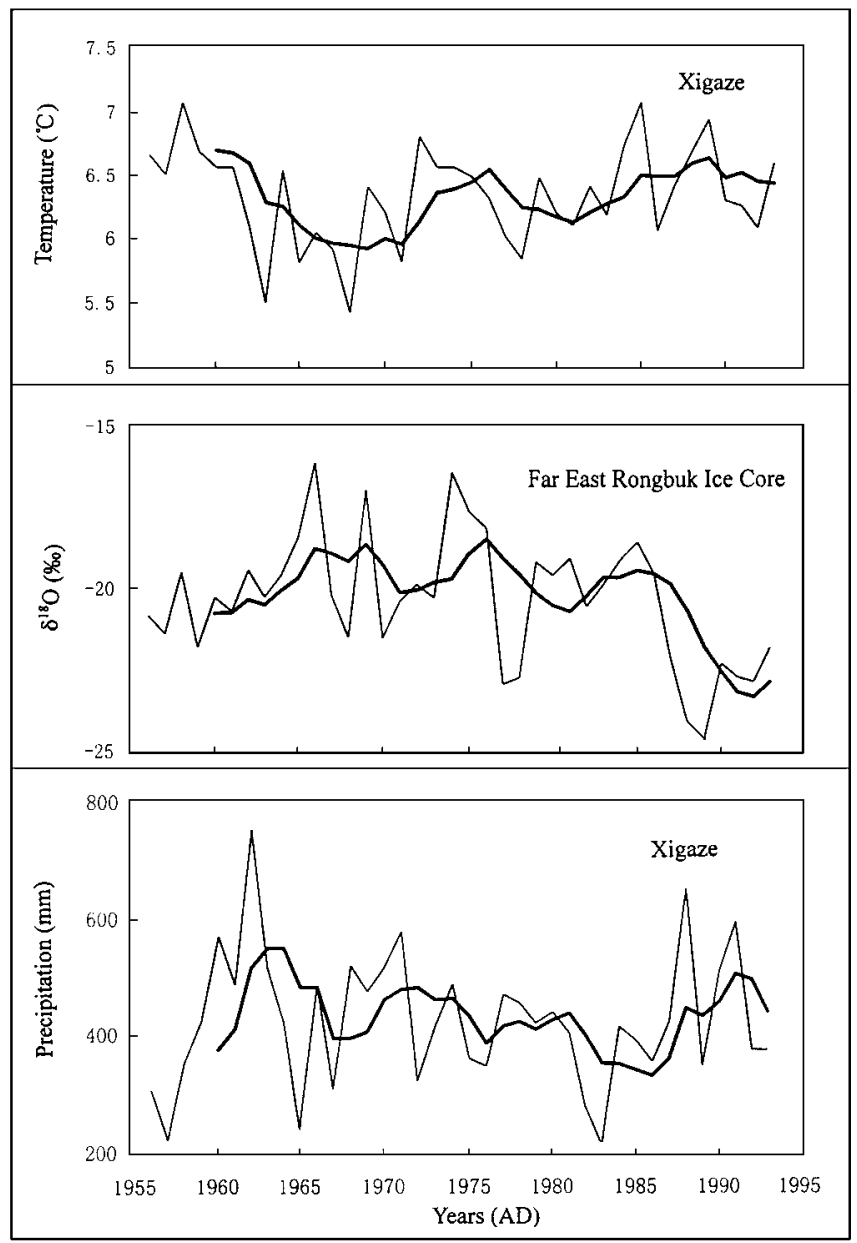

Figure 5 The comparison of $\delta^{18} \mathrm{O}$ in the Far East Rongbuk ice core and temperature, precipitation at Xigaze (the fine line is annual value, the coarse line is 11 points smoothing value).

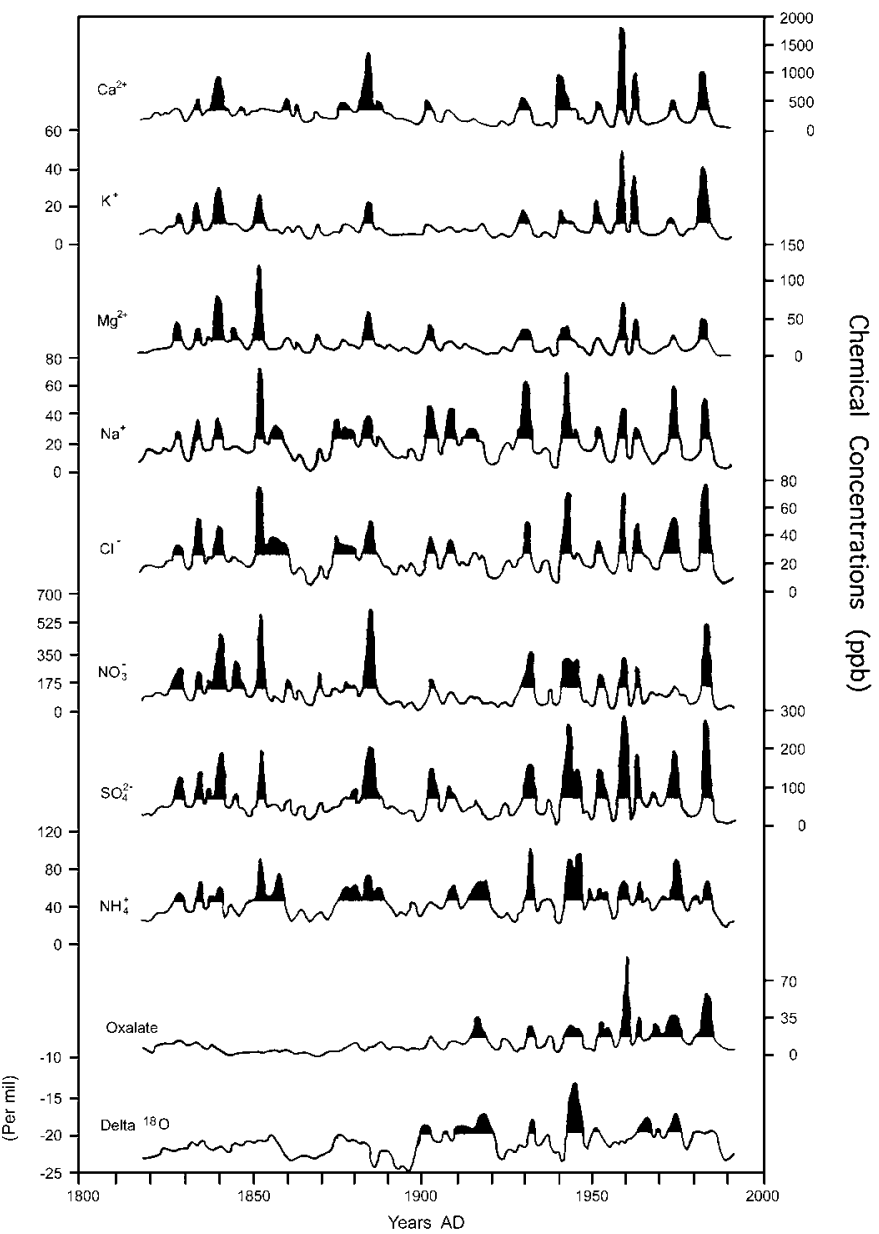

Figure 6 The 11 points smoothing curve of chemical species in Far East Rongbuk ice core (black parts are higher than average value).

\section{Oxalate records from FER ice core}

Oxalate is one of the carboxylic acids. Despite their potentially important role in tropospheric chemistry (Galloway, 1982; Keene et al., 1986), few investigations of snow carboxylic acids have been conducted in remote areas, particularly in Asia. From the FER ice core record, the most outstanding feature is the $\mathrm{C}_{2} \mathrm{O}_{4}{ }^{2-}$ increase since the beginning of the 20th century (Figures 2,6,7). Fluctuations of $\mathrm{C}_{2} \mathrm{O}_{4}{ }^{2-}$ are small in the 19th century (Figure 7), probably the result of seasonal fluctuations. However, in the 20th century, especially during the $1950 \mathrm{~s} \sim 1980 \mathrm{~s}$, many peaks of $\mathrm{C}_{2} \mathrm{O}_{4}{ }^{2-}$ concentrations occur and the fluctuations are very dramatic, indicating that short episodes with high $\mathrm{C}_{2} \mathrm{O}_{4}{ }^{2-}$ concentrations account for elevated mean values in 20th century.

Carboxylic acids come from vegetation emissions and biomass burning (Talbot et al., 1988; Andreae et al., 1988; Legrand et al., 1992), the oxidation of various alkenes (Jacob, 1986) and anthropogenic emissions (Talbot et al., 1988; Legrand et al., 1995). The increasing tendency of $\mathrm{C}_{2} \mathrm{O}_{4}{ }^{2-}$ concentrations in the 20th century is not consistent with that of $\mathrm{Ca}^{2+}$, which is representative of atmospheric dust (Kang et al, 2000) in Himalayas (Figure 2), suggesting that the source of $\mathrm{C}_{2} \mathrm{O}_{4}{ }^{2-}$ has very little relation to atmospheric dust. $\mathrm{NH}_{4}{ }^{+}$come partly from biogenic sources in Himalayas (Mayewski et al., 1983; Davidson et al., 1986) but the general trend of variations is not obvious (Figure 7). However, the perturbations of $\mathrm{C}_{2} \mathrm{O}_{4}{ }^{2-}$ are larger than those of $\mathrm{NH}_{4}{ }^{+}$in the 20th century, suggesting that the 20th century increase of $\mathrm{C}_{2} \mathrm{O}_{4}{ }^{2-}$ concentrations is not mainly related to biogenic sources and thus caused by other sources. Ice core $\delta^{18} \mathrm{O}$ has increased since the beginning of 20th century and the general 

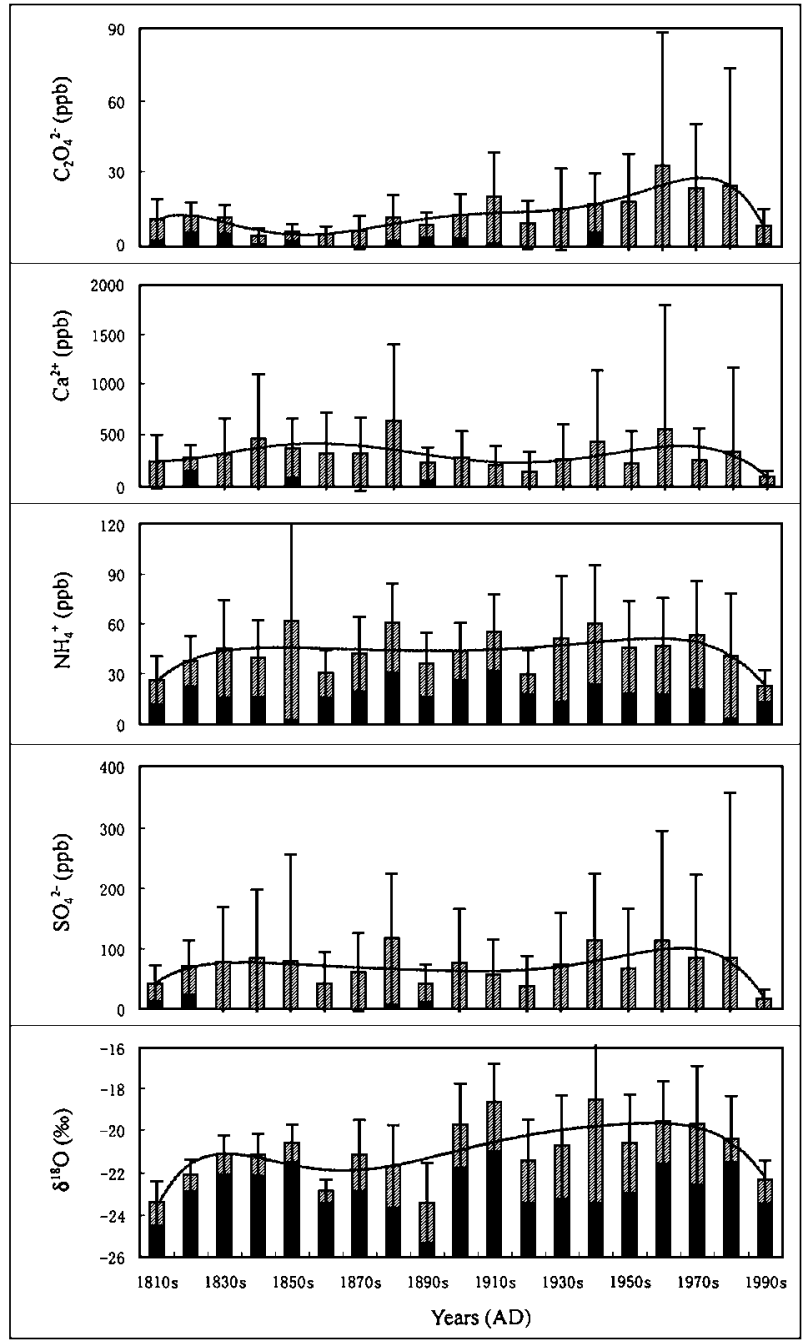

Figure 7 Variations of 10-year mean of $\mathrm{C}_{2} \mathrm{O}_{4}^{2-}, \mathrm{Ca}^{2+}, \mathrm{NH}_{4}^{+}$and $\mathrm{SO}_{4}{ }^{2-}$ concentrations and $\delta^{18} \mathrm{O}$ value and their tendencies from FER ice core. Dashed lines represent the multinomial of the power of six. Error bars represent \pm 1 standard deviation.

tendency of $\delta^{18} \mathrm{O}$ variations agree with $\mathrm{C}_{2} \mathrm{O}_{4}{ }^{2-}$ (Figure 2 and 7). However, the increase of $\mathrm{C}_{2} \mathrm{O}_{4}{ }^{2-}$ in 20th century is more dramatic than that of $\delta^{18} \mathrm{O}$, therefore, the temperature increase may influence the $\mathrm{C}_{2} \mathrm{O}_{4}{ }^{2-}$ concentration (e.g. the strength of the emissions by vegetation or the oxidation of various alkenes) but is not necessarily the dominant factor for higher $\mathrm{C}_{2} \mathrm{O}_{4}{ }^{2-}$ concentrations in the 20th century, notably in the 1950s 1980s.

Oxalate has been mass-produced by industry since the $1940 \mathrm{~s}$ (e.g. in Germany) (Hong, 1997). Thus we assume that $\mathrm{C}_{2} \mathrm{O}_{4}{ }^{2-}$ concentrations in the 19th century were not influenced by industrial emissions and may represent natural background values, while higher $\mathrm{C}_{2} \mathrm{O}_{4}{ }^{2-}$ concentrations, especially those peaks due to short episodes in 1950s 1980s, may be caused by industrial emissions. Though the transportation and deposition for these industrial $\mathrm{C}_{2} \mathrm{O}_{4}{ }^{2-}$ pollutants from source regions to mountain glaciers is not well known, the ice core $\mathrm{C}_{2} \mathrm{O}_{4}{ }^{2-}$ record from Mt. Qomolangma (Mt. Everest) provides a unique opportunity to assess the contribution of anthropogenic emissions to background $\mathrm{C}_{2} \mathrm{O}_{4}{ }^{2-}$ concentration. In the middle of the 20th century, industrial production of oxalate was high and the pollution could not be controlled. After that, industrial pollution has been severely controlled and lots of factories for producing oxalate had closed all over the world (Hong, 1997). This may be the cause of the lower $\mathrm{C}_{2} \mathrm{O}_{4}{ }^{2-}$ concentrations in the 1990s.

\section{Acknowledgments}

This research is supported by NSF of US, the Great Project of Chinese Academy of Sciences (KZ951-A1-402, 204), the National Natural Science Foundation of China (49871022, G19980408), and a cooperative project between Cold and Arid regions Environmental and Engineering Research Institute, CAS and Institute for Quaternary and Climate Studies, University of Maine. We thank members of 1997 Sino-American Cooperative Glaciological Expedition in Mt. Qomolangma (Mt. Everest) for assistance in the field, and Sallie Whitlow and Weizheng Sun for analyzing samples.

\section{References}

Andreae, M. O., and 14 others, 1988, Biomass-burning emission and associated haze layers over Amazonia. J. Geophys. Res., 93(D2): 1509-1527.

Buck, C. F., and Mayewski,P. A., 1992. Determination of major ions in snow and ice cores by ions chromatography. Journal of Chromatography, 594: 225-228.

Davidson, C. I., Lin, S, Osborn, J. F., Pandey, M. R., Rasmussen, R. A., and Khalil, M. A. K., 1986, Indoor and outdoor air pollution in the Himalayas. Envir. Sci. Technol., 20, 561-567.

Galloway, J. N., Likens, G. E., Keene, W. C., and Miller, J. M., 1982, The composition of precipitation in remote areas of the world. J. Geophys. Res., 87(11), 8771-8786.

Gao, Y., Arimoto, R., Zhou, M., Merrill, J., and Duce, R. A., 1992, Relationships between the dust concentration over eastern Asia and the remote north Pacific, J. Geophys. Res., 97, 9867-9872.

Hong, Z. eds, 1997, Deeply processing of organic industrial chemicals. Beijing, Chemical Industry Press, 421-438. (In Chinese)

Hou, S., Qin, D., Wake, C. P., and Mayewski, P. A., 1999. Abrupt decrease in recent snow accumulation at Mount Qomolangma (Everest), Himalaya. Journal of Glaciology, 45(151): 585-586.

Jacob, D. J., 1986, The chemistry of $\mathrm{OH}$ in remote clouds and its role in the production of formic and peroxymonosulfate. J. Geophys. Res., 91: 9807-9826.

Jones, P. D., Raper, S. C. B., Bradley, R. S., et al., 1986. Northern Hemisphere surface air temperature variations: 1851-1984. Journal of Climate and Applied Meteorology, 25: 161-178.

Kang, S., Li, J., Yao, T., et al., 1998, A study of the climate variation in the Tibetan Plateau during the last 50 years. Journal of Glaciology and Geocryology, 20(4): 381-387.

Kang, S., Wake, C. P., Qin, D, Mayewski, P. A., and Yao, T., 2000, Monsoon and dust signals recorded in the Dasuopu Glacier, Tibetan Plateau. J. Glaciol., 46(152):

Keene, W. C., and Galloway, J. N., 1986, Consideration regarding sources for formic and acetic acids in the troposphere. J. Geophys. Res., 91 14446-14474.

Legrand M., Angelis, M. D., 1995, Origins and variations of light carboxylic acids in polar precipitation. Journal of Geophysical Research, 100(D1): 1445-1462.

Legrand, M., De Angelis, M., Staffelbach, T., Neftel, A., and Stauffer, B., 1992. Large perturbations of ammonium and organic acids content in the Summit-Greenland ice core. Fingerprint from forest fires?. Geophys. Res. Lett., 19(5), 434-475.

Liang F., 1997. Climatic analysis for the weather of dust storms in QinghaiTibetan Plateau. in: Fang Z. et al., eds, Studies on dust storms in China. Beijing: Meteorology Press, 16-21. (In Chinese)

Lyons, W. B., Wake, C. and Mayewski,P. A., 1991, Chemisty of snow from high altitude/mid-low latitude regions, NATO ASI Series, Vol. G28, in Seasonal Snowpacks, ed. Davies et al., Springer Verlag, Berlin and Heidelberg, 359-383.

Mayewski, P.A., Lyons, W. B., and Ahmad, N., 1983, Chemical composition of a high altitude fresh snowfall in the Ladakh Himalayas. Geophys. Res. Lett., 10, 105-108.

Mayewski, P. A., Lyons, W. B., Ahmad, N., Smith, G., and Pourchet, M., 1984, Interpretation of the chemical and physical time-series retrieved from Sentik Glacier, Ladakh Himalaya, India, J. Glaciol., 30, 66-76.

Mayewsli, P. A., Lyons, W. B., and Ahmad, M., 1981, Reconnaissance glacio-chemical studies in the Indian Himalayas, 38th Annual Eastern Snow Conference, Syracuse, New York, 45-48. 
Merrill, J. T., Uematsu, M., and Bleck, R., 1989, Meteorological analysis of long range transport of mineral aerosol over the north Pacific. J. Geophys. Res., 94, 8584-8598.

Murakami, T., 1987. Effect of the Tibetan Plateau, in Chang C. and Krishnamurti, T. N., eds, Monsoon meteorology, Oxford University Press, New York, 235-270.

Qian, Z., H. He, Z. Huo, et al., 1997, The classification and statistical characteristics of samples of dust storms in northwestern China. in Fang Z. eds, Studies on dust storm in China. Meteorology Press, Beijing, 1-10. (In Chinese)

Qin, D., Mayewski, P. A., Wake, C. P. et al., 2000. Evidence for recent climate change from ice cores in the central Himalaya. Annals of Glaciology, 31 .

Rozanski, K., Araguás-Araguás, L. and Gonfiantini,.R., 1992. Relation between long-term trends in oxygen-18 isotope composition of precipitation and climate. Science, 258, 981-985.

Shrestha, A. B., Wake, C., and Dibb, J., 1997, Chemical composition of aerosol and snow in the high Himalaya during the summer monsoon season. Atmos. Environ., 31(17), 2815-2826.

Sontakke N A, Nityanand Singh, 1996, Longest instrumental regional and all-India summer monsoon rainfall series using optimum observations: reconstruction and update. The Holocene, 6: 315-331.

Talbot, R. Beecher, W. K. M., Harriss, R. C., and Cofer, W. R., 1988, Atmospheric geochemistry of formic and acetic acids at a mid-latitude temperature site. J. Geophys. Res., 93(D2): 1638-1652.

Thompson, L. G., Mosley-Thompson, E., Davis, M,. Lin, P. N., Mikhalenko, V. and Dai, J., 1995a, A 1000 year ice core climate record from Guliya Ice Cap, China and its relationship to global climate variability. Annal. of Glaciol., 21, 175-181.

Thompson L. G., Mosley-Thompson, E., Davis, M. et al., 1995b, Late glacial stage and Holocene tropical ice core records from Huascaran, Peru. Science, 269: 46-50.

Thompson L. G., Mosley-Thompson, E., Davis, M., Bolzan, J., Dai, J., Gundestrup, N., Yao, T., Wu, X. and Xie,Z., 1989, Holocene-Late Wisconsin Pleistocene climatic ice core records from Qinghai-Tibetan Plateau. Science 246 (4929), 474-477.

Thompson L. G., Yao, T., Davis, M., Henderson, K. A., Mosley-Thompson, E., Lin, P. N., Beer, J., Synal, H.-A., Cole-Dai, J., and Bolzan, J., 1997. Tropical climate instability: The last glacial cycle from a QinghaiTibetan ice core. Science, 276, 1821-1825.

Kang Shichang, born in 1969 at Longxi, Gansu Province, China; received M.Sc. from Lanzhou University in 1995 and Ph.D. from Lanzhou Institute of Glaciology and Geocryology, Chinese Academy of Sciences in 1999; postdoctoral scholar in University of Maine, USA, since 2000. His scientific interest is climatic and environmental change recovered from snow/ice records. There are more than 20 publications related to climate change, atmospheric environment and glaciochemistry from Arctic and Qinghai-Tibetan Plateau.
Thompson L.G., Wu, X., Moskey-Thompson, E. and Xie, Z., 1988. Climatic records from the Dunde ice cap, China. Ann. Glaciol., 10, 178-182.

Thompson L. G., T. Yao, E. Mosley-Thompson, M. E. Davis, K. A. Henderson P. N. Lin, 2000, A high-resolution millennial record of the south Asian monsoon from Himalayan ice cores. Science, 289, 1916-1919.

Wake C. P., and Stievenard, M.,1995, The amount effect and oxygen isotope ratios recorded in Himalayan snow, Paleoclimate and Environmental Variability in Austral-Asian Transect during the Past 2000 Years, Proceedings of the 1995 Nagoya IGBP-PAGES/PEP-II Symposium, 236-241.

Wake C. P., Dibb, J., Mayewski, P. A., Xie, Z., Li, Z., Wang, P., and Qin, D., 1994, The chemical composition of aerosols over eastern Himalaya and Tibetan Plateau during low dust periods. Atmos. Environ., 28, 695-704.

Wake C. P., Mayewski, P. A., and Spencer, M. J., 1990, A review of central Asian glaciochemisty data, Annal. Glaciol., 14, 301-306.

Wake, C. P., Mayewski, P. A., Xie, Z., Wang, P., and Li, Z.,1993, Regional variation of monsoon and desert dust signals record in Asian glaciers. Geophys. Res. Lett. 20, 1411-1414.

Wushiki, H., 1977, Deuterium content in the Himalayan precipitation at Khumbu District, observed in 1974/1975. SEPPYO (Journal of the Japanese Society of Snow and Ice), 39 (Special Issue), 50-56.

Xu Q., and Hu, J.,1997, The analysis of temporal and spatial distribution of dust storm weather in northwestern China. Studies on dust storms in China. Beijing: Meteorology Press, 11-15. (In Chinese).

Yao, T. and Thompson, L. G., 1992, Trends and features of climatic changes in the past 5000 years recorded by the Dunde ice core. Annal. Glaciol., $16,21-24$.

Yao, T., Thompson, L. G., Mosley-Thompson, E., Yang, Z., Zhang, X., and Lin, P. N., 1996a, Climatological significance of $\delta^{18} \mathrm{O}$ in north Tibetan ice cores. J. Geophys. Res., 101(D23), 29,513-29,537.

Yao T., Thompson, L. G., Qin, D. et al., 1996b, Variations in temperature and precipitation in the past 2000 a on the Xizang (Tibet) Plateau-Guliya ice core record. Science in China (Series D), 39(4): $425-433$.

Yao, T., Thompson, L. G., Jiao, K., Mosley-Thompson, E., and Yang, Z., 1995, Recent warming as recorded in the Qinghai-Tibetan Plateau Cryosphere. Annal. Glaciol., 21, 196-200.

Zheng B. and Shi, Y., 1975, Glacier flactuation in Mt. Qomolangma region. Glacier and Glacial Geomorphology, from the Scientific Report of Mt. Qomolangma Expedition (1966-1968). Beijing, Science Press, 92-105. (in Chinese)

Qin Dahe, professor, born in Lanzhou, Gansu, China in 1947, received $B$. Sc. in 1970, M.Sc. in 1981 and Ph.D. in 1992 from Lanzhou University. Since 1978 he has been devoting himself to research work on glaciology and climatic change in Lanzhou Institute of Glaciology and Geocryology (renamed Cold and Arid regions Environmental and Engineering Research Institute in 1999), Chinese Academy of Sciences. He has participated in and organized many expeditions to high mountains in west China and Antarctica on glaciological investigation, and has contributed great efforts to develop glaciological and cold regions envrionmental research in China.

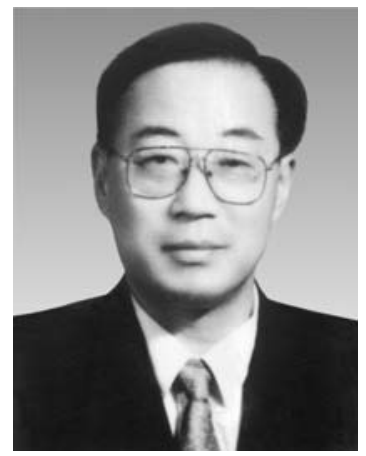

